\title{
Dead Chromosome Walking
}

\begin{abstract}
A review of: Rozen S, Skaletsky H, Marszalek JD, Minx PJ, Cordum HS, Waterston RH, Wilson RK, Page DC 2003 Abundant gene conversion between arms of palindromes in human and ape Y chromosomes. Nature 423:873-876; and Skaletsky H, Kuroda-Kawaguchi T, Minx PJ, Cordum HS, Hillier L, Brown LG, Repping S, Pyntikova T, Ali J, Bieri T, Chinwalla A, Delehaunty A, Delehaunty K, Du H, Fewell G, Fulton L, Fulton R, Graves T, Hou SF, Latrielle P, Leonard S, Mardis E, Maupin R, McPherson J, Miner T, Nash W, Nguyen C, Ozersky P, Pepin K, Rock S, Rohlfing T, Scott K, Schultz B, Strong C, Tin-Wollam A, Yang SP, Waterston RH, Wilson RK, Rozen S, Page DC 2003 The male-specific region of the human Y chromosome is a mosaic of discrete sequence classes. Nature 423:825-837
\end{abstract}

$I^{i}$ SS FATE HAD been decided. After millions of years of loyal service to masculinity, the $\mathrm{Y}$ chromosome was doomed to a slow, yet certain extinction. Its swan song was SRY, the gene of masculinity that makes boys become boys.

Although the $\mathrm{Y}$ chromosome contains mostly unique, Y-specific sequences, it shares a small $(2.6 \mathrm{Mb})$ homologous region (PAR1, Pseudo Autosomal Region 1) with the X chromosome that allows $\mathrm{X}$ and $\mathrm{Y}$ pairing at their respective short arms. The presence of homologous regions in the $\mathrm{X}$ and $\mathrm{Y}$ chromosomes supports the idea, initially formulated by Susumo Ohno, that both chromosomes evolved from a pair of autosomes (1).

At some point in evolution, a sexdetermining locus, probably SRY, arose on one of these proto-sex chromosomes, resulting in the accumulation of other sex-specific alleles nearby. As time went on, it became favorable to inherit the sex-specific region as a whole, and recombination between increasing parts of the future sex chromosomes progressively stopped, allowing the accumulation of deleterious mutations and the eventual "shrinking" of the Y chromosome (2). Comparative cytogenetics suggests that the $\mathrm{Y}$ chromosome evolved after the divergence of mammals from reptiles ( -310 Million years), but before the divergence of marsupials and eutherians from monotremes ( -170 Million years).

The cost of being a sex-determining chromosome was to slowly disinte-

\section{ERIC VILAIN}

grate and lose most functional genes. The modern day picture of the Y chromosome is not a pretty one. Within the $63 \mathrm{Mb}$ of male-specific Y chromosome, that does not recombine with the $\mathrm{X}$ chromosome, about two thirds (40Mb) are heterochromatic repetitive DNA, which is traditionally viewed as non functional, and about one third (23Mb) is euchromatic DNA, which encodes only a small number of genes (about $60)$. If the prevailing theory is accurate, it is predicted that the $\mathrm{Y}$ chromosome will entirely disappear within 5-10 million years (3).

In spite of this bleak picture, there is hope! By undertaking the daunting task of sequencing the entire euchromatic region of the $\mathrm{Y}$ chromosome, David Page and colleagues have identified a unique feature, "ampliconic" regions composed of large, highly similar (up to 99.9\%) palindromes, the sequence homogeneity of which is maintained by intrachromosomal gene conversion events (4). Seven ampliconic regions that cover 10.2 $\mathrm{MB}$, almost half of the euchromatic Y chromosome, contain 60 protein-encoding genes, and 75 transcription units of unknown significance.

The biological implication that these ampliconic structures facilitate selfrecombination between the arms of the palindromes on the $\mathrm{Y}$ chromosome is potentially far reaching (5). The possibility of gene conversion within amplicons provides unique survival skills for a chromosome that was initially thought doomed because of its inability to recombine with a homologous chromosome. To evaluate the frequency of gene conversion, a particular gene in a palindrome was sequenced throughout several generations of a known Y chromosome genealogy. From this study, it was estimated that an average of 600 nucleotides undergo arm-to-arm gene conversion in each male newborn of the human population (5). In addition, because of the almost identical sequences between each palindromic arm of humans and chimpanzees, it is hypothesized that the rate of gene conversion is high enough to allow the repair of new mutations as fast as they appear.

The consequences of these findings are broad. First, they change our perspective of the genome from static to dynamic since gene conversion may be much more common than previously thought. Second, they open a unique window on the history and evolution of sex-chromosomes, which would not have been appreciated had it not been for the thankless task of sequencing the chromosomes of many species. Finally, they challenge the concept of "junk" DNA. Studies of the Y, the epitome of "junk" genetic material, show that even the most repetitive sequences may have a biological function. Microarray-based expression studies start to reveal unsuspectingly high levels of transcriptional activities throughout the genome, up to an order of magnitude more than predicted by the analysis of the genomic sequences (6). Comparative analyses of large 
genomic fragments between vertebrates show conservation of many noncoding segments, hinting at a crucial, as yet unclear, functional role (7).

Dogma in molecular biology is short lived. The Y chromosome saga, which was supposed to end in a tragedy, may yet have a happy ending. The pronouncement at the death of European monarchs seems suitable for the $\mathrm{Y}$ chromosome: "The King is dead, long live the King."

1. Ohno S 1967 Sex Chromosomes and Sex Linked Genes. Springer-Verlag, New York.

2. Marshall-Graves JA 2002 The rise and fall of SRY. Trends Genet 18:259-264

3. Aitken RJ, Marshall-Graves JA 2002 The future of sex. Nature 415:963

4. Skaletsky H, Kuroda-Kawaguchi T, Minx PJ, Cordum HS, Hillier L, Brown LG, Repping S, Pyn- tikova T, Ali J, Bieri T, Chinwalla A, Delehaunty A, Delehaunty K, Du H, Fewell G, Fulton L, Fulton R, Graves T, Hou SF, Latrielle P, Leonard S, Mardis E, Maupin R, McPherson J, Miner T, Nash W, Nguyen C, Ozersky P, Pepin K, Rock S, Rohlfing T, Scott K, Schultz B, Strong C, Tin-Wollam A, Yang SP, Waterston RH, Wilson RK, Rozen S, Page DC 2003 The male-specific region of the human $\mathrm{Y}$ chromosome is a mosaic of discrete sequence classes. Nature 423:825-837

5. Rozen S, Skaletsky H, Marszalek JD, Minx PJ, Cordum HS, Waterston RH, Wilson RK, Page DC 2003 Abundant gene conversion between arms of palindromes in human and ape $\mathrm{Y}$ chromosomes. Nature 423:873-876

6. Kapranov P, Cawley SE, Drenkow J, Bekiranov S, Strausberg RL, Fodor SP, Gingeras TR 2002 Largescale transcriptional activity in chromosomes 21 and 22. Science 296:916-919

7. Thomas JW, Touchman JW, Blakesley RW, Bouffard GG, Beckstrom-Sternberg SM, Margulies EH, Blanchette M, Siepel AC, Thomas PJ, McDowell JC, Maskeri B, Hansen NF, Schwartz MS, Weber RJ, Kent WJ, Karolchik D, Bruen TC, Bevan R, Cutler DJ, Schwartz S, Elnitski L, Idol JR, Prasad AB, Lee-Lin SQ, Maduro VV, Summers TJ, Portnoy ME, Dietrich NL, Akhter N, Ayele K, Benjamin B,
Cariaga K, Brinkley CP, Brooks SY, Granite S, Guan X, Gupta J, Haghighi P, Ho SL, Huang MC, Karlins E, Laric PL, Legaspi R, Lim MJ, Maduro QL, Masiello CA, Mastrian SD, McCloskey JC, Pearson R, Stantripop S, Tiongson EE, Tran JT, Tsurgeon C, Vogt JL, Walker MA, Wetherby KD, Wiggins LS, Young AC, Zhang LH, Osoegawa K, Zhu B, Zhao B, Shu CL, De Jong PJ, Lawrence CE, Smit AF, Chakravarti A, Haussler D, Green P, Miller W, Green ED 2003 Comparative analyses of multi-species sequences from targeted genomic regions Nature 424:788-793

David Geffen School of Medicine at UCLA UCLA Departments of Human Genetics, Pediatrics and Urology

Box 957088, 6357C Gonda Cntr

Los Angeles, CA 90095

evilain@ucla.edu

DOI: 10.1203/01.PDR.0000123762.03212.B1 